\title{
The Effect Of Cigarette Smoke On The Folliculogenesis Process In Mice (Mus Musculus)
}

\author{
Jenie Palupi \\ Health Polytechnic of Malang, Republic of Indonesia Jl. Besar Ijen 77 C, Phone: 0341-566075, fax: 0341- \\ 556746
}

\begin{abstract}
Nowadays, smoking is a very familiar sight. Smoking habits are considered to provide enjoyment for the smoker, however on the other hand they can cause negative effects for the smokers themselves and those around them. Research on the effects of smoking in women has not been done, whereas women, who do not smoke, are one of the victims of exposure to cigarette smoke from husbands / men who smoked. This research generally aims to study the effect of cigarette smoke on the folliculogenesis process in mice (Mus muscullus), which includes the establishment of primary follicle, secondary follicle, tertiary follicle and follicle de graaf.

The research was conducted in subjects with variation of cigarette smoke dosage. K1 group as a control group was given the aroma therapy smoke to its mice. K2 group was given 1 dose / 24 hour smoke. K3 group was given 2 doses / 24 hour smoke. K4 group was given 3 doses / 24 hour smoke in all treatment groups. The hypothesis is tested with two-way analysis of variance, in which the first factor is exposure to cigarette smoke and the second is the day of observation. Exposure to cigarette smoke within 6 weeks has significant effect on the formation of primary follicle in mice. The overall exposure to cigarette smoke is 2 weeks, 4 weeks and 6 weeks that has significant effect on the formation of secondary follicle in mice. While, it has no significant effect on the formation tertiary follicle in mice. Exposure to cigarette smoke in a period of 6 weeks has no significant effect on the formation of follicle de graaf in mice.
\end{abstract}

Keywords: Exposure to cigarette smoke, the day of observation, primary follicle, secondary follicle, tertiary follicle and follicle de graaf.

\section{Introduction}

Infertility can be caused by many factors. The factor that plays an important role in contributing to the occurrence of infertility is lifestyle, which is equal to 15-20\% (Anwar, 2000). The lifestyle includes smoking, alcohol, caffeine, drugs and execessive exercises. Nowadays, smoking is a very familiar sight. Smoking habits are considered to provide enjoyment for the smoker, but on the other hand they can cause negative effects for the smokers themselves and those around them. There are many research on the impact of smoking on fertility in males. Effects of smoking, especially the nicotine, can lead to reduced sperm volume, sperm motility, sperm shape and capacity as well as increased seminal stress and DNA damage (Arabi, 2005; Mostafa, 2010). However, the research on the effects of smoking in women has not been done, whereas women, who do not smoke, are one of the victims of exposure to cigarette smoke from husbands / men who smoked. These conditions will increase if she herself is a smoker. Therefore, researchers wanted to examine how the effects of cigarette smoke exposure on the fertility of a woman. The women fertility is portrayed by the ability of ovaries to produce ova called unsafe folliculogenesis (Susanto, 2007).

\section{General Objective}

This research generally aims to study the effect of cigarette smoke on the folliculogenesis process in mice ( Mus musculus ).

\section{Specific Objectives}

In particular, this study aims to :

1. Study the effect of cigarette smoke on the formation of primary follicle.

2. Study the effect of cigarette smoke on the formation of secondary follicle.

3. Study the effect of cigarette smoke on the formation of tertiary follicle.

4. Study the effect of cigarette smoke on the formation of follicle de Graaf.

\section{Hyphotesis}

1. Distribution of cigarette smoke in mice does not inhibit the growth number of primary ovarian follicle of mice.

2. Distribution of cigarette smoke in mice does not inhibit the growth number of secondary ovarian follicle of mice. 
3. Distribution of cigarette smoke in mice does not inhibit the growth number of tertiary ovarian follicle of mice.

4. Distribution of cigarette smoke in mice does not inhibit the growth number of mouse ovarian follicle de Graaf.

\section{Framework}

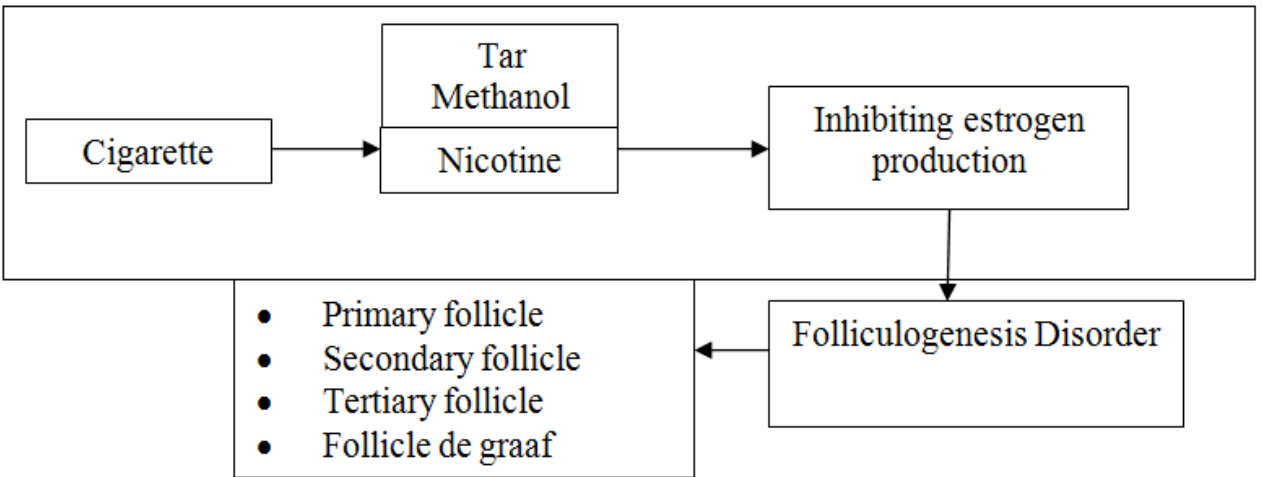

\section{Method}

Design:

This research is a kind of experimental laboratory post-test design with experimental and control groups (Post test only control group design). Schematically, this research design can be described as follows:

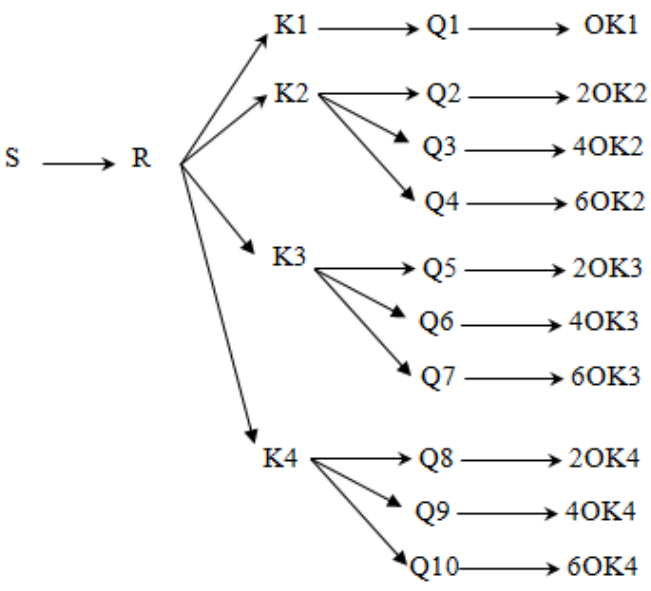

Image 3.1 Research Plan Chart

Description:

S: Sample

$\mathrm{R}$ : Randomization

$\mathrm{K} 1$ : The control group was given the aroma therapy smoke

K2: Treatment group I, mice were given 1 dose / 24 hour smoke

K3: Treatment group II mice were 2 dose / 24 hour smoke

K4: Treatment group III mice were 3 dose / 24 hour smoke

Q1: Treatment control

Q2: Treatment Part I for 2 weeks

Q3: Treatment Part I for 4 weeks

Q4: Treatment Part I for 6 weeks

Q5: Treatment Part II for 2 weeks

Q6: Treatment Part II for 4 weeks

Q7: Treatment Part II for 6 weeks

Q8: Treatment Part III For 2 weeks

Q9: Treatment Part III For 4 weeks

Q10: Treatment Part III for 6 weeks

OK1: The results of the control treatment 
2OK2: Results of Treatment I for 2 weeks

4OK2: Results of Treatment I for 4 weeks

6OK2: Results of Treatment I for 6 weeks

2OK3: Results of Treatment II for 2 weeks

4OK3: Results of Treatment II for 4 weeks

6OK3: Results of Treatment II for 6 weeks

2OK4: Results of Treatment III for 2 weeks

4OK4: Results of Treatment III for 4 weeks

6OK4: Results of Treatment III for 6 weeks

The study was conducted in subjects with dose variation smoke $\mathrm{K} 1$ group as a control group given the smoke aroma therapy in mice. K2 group was given 1 dose / 24 hour smoke. K3 group was given 2 doses / 24 hour smoke. K4 group was given 3 doses / 24 hour smoke in all treatment groups.

The treatment in K1 to K4 group is given once a day. After being treated for 2, 4 and 6 weeks, then the surgery to take her ovaries have been determined in accordance weeks ie 2, 4 and 6 weeks. The results of surgery results are made to be preparat to see the growth of follicles. The results of the examination of nine treatment groups are compared with the control.

\section{Experiment Unit and Replication}

The experiment unit are chosen mice that meet the following requirements :

1. Age of experimental animals $8-10$ weeks

2. Have ever been in gravid condition

3. Healthy, characterized by active movement

The amount of replication sample is determined by Cochran formula (1986) defined as follows :

$(\mathrm{T}-1)(\mathrm{r}-1) \geq 20$

$(10-1)(r-1) \geq 20$

$9(\mathrm{r}-1) \geq 20$

$9 \mathrm{r}-9 \geq 20$

$9 \mathrm{r} \geq 29$

$\mathrm{r} \geq 3.2$

Based on calculations obtained a sample of 40 mice were divided into 10 groups, each consisting of four groups of experimental animals . To determine the mice ( Mus musculus ) into the group, the samples are taken randomly complete.

\section{Research Variable}

Variables Classification

1. Independent Variable

a. Cigarette smoke 1 dose / 24 hours for 2,4 and 6 weeks

b. Cigarette smoke 2 doses / 24 hours for 2,4 and 6 weeks

c. Cigarette smoke 3 doses / 24 hours for 2,4 and 6 weeks

2. Dependent Variable

a. The number of primary follicle

b. The number of secondary follicle

c. The number of tertiary follicle

d. The number of follicle de Graaf

3. Control Variable

a. Type of Experimental Animals

b. Sex of Experimental Animals

c. Have ever been in gravid condition

d. Age of Experimental Animals

e. Feed, maintenance and care of experimental animals

f. Physical health of experimental animals

g. Sanitation

h. Drinking water

i. Treatment time

\section{Result And Discussion}

The Effect of Cigarette Smoke toward the Establishment of Primary Follicle

Univariat Anova test is used to understand the number of primary follicle difference between groups. Univariat Anova test results can be seen in the following table : 
Table 4.4: Univariat Anova test results on the number of primary ovarian follicle of mice with cigarette smoke exposure for few weeks

\begin{tabular}{|l|l|l|l|l|l|l|}
\hline $\begin{array}{l}\text { Sources of } \\
\text { Diversity }\end{array}$ & $\begin{array}{l}\text { Sum of } \\
\text { Squares }\end{array}$ & $\begin{array}{l}\text { Degree of } \\
\text { Freedom }\end{array}$ & $\begin{array}{l}\text { Mean } \\
\text { Square }\end{array}$ & F-ratio & Significance & Description \\
\hline $\begin{array}{l}\text { Cigarette smoke } \\
\text { Observation }\end{array}$ & 3,583 & 3 & 1,194 & 1,284 & 0,295 & $\begin{array}{l}\text { Non-significant } \\
\text { Significant } \\
\text { Interaction }\end{array}$ \\
Error & 26,792 & 2 & 13,396 & 14,396 & 0,000 & Non- significant \\
Total & 10,042 & 6 & 1,674 & 1,799 & 0,127 & \\
& 33,500 & 36 & 0,931 & & & \\
\hline
\end{tabular}

According to the table above, the number of primary ovarian follicle of mice with exposure to cigarette smoke in Univariat Anova test in a few weeks showed that exposure to cigarette smoke did not affect the number of primary follicle significantly, with the F-ratio equal to 1.284 and a significance of 0.295 . Weeks of observation factor affects the number of primary follicle significantly, with the F-ratio equal to 14.396 and the significance of 0.000 . While, the interaction between cigarette smoke exposure and weeks of observation had no significant effect on the number of primary follicle with the F-ratio equal to 1.799 and a significance of 0.127 .

Table 4.5: HSD-Turkey test results on the number of primary ovarian follicle of mice with cigarette smoke

\begin{tabular}{|l|c|}
\multicolumn{2}{c|}{ exposure for few weeks } \\
\hline Weeks of Observation & Total Number of Primary Follicle \\
\hline 2 Weeks & $7,190 \quad$ a \\
4 Weeks & $6,060 \quad$ a \\
6 Weeks & $5,380 \quad$ b \\
\hline
\end{tabular}

According to the table above, HSD-Turkey test results on the number of primary ovarian follicle of mice with cigarette smoke exposure for few weeks showed that the observation of 2 weeks and 4 weeks had no significant difference, but significantly different from the observation of 6 weeks. 6 weeks observation resulted in the lowest number of primary follicle that is equal to 5.380 .

Exposure to cigarette smoke contains many toxic compounds to the body. Ninety eight of 2256 compounds in cigarette smoke can damage the health through inhalation ( Talhout R, 2011). Some of those compounds such as polycyclic aromatic hydrocarbons ( PAH ) [ eg, benzo (a) pyrene ( BAP ), acenapthelene , phenanthrene, pyrene and Chrysene ], nitrosamines, heavy metals [ eg, cadmium (Cd), lead and ] cobalt, alkaloids (nicotine), aromatic amines and so forth (Kaiserman and Ricky, 1992;. Ding et al , 2005).

The invitro process of maturation of oocytes (ova) is characterized by the cumulus oophorus which surround the oocyte (Goto, et al, 1995). Cumulus expansion emphasis is stimulated by FSH. There is the inhibitory effect of cumulus expansion of cadmium and nicotine on the synthesis and accumulation of hyaluronic acid in the cell compartment / matrix OCC. The inhibitory effect of the compounds tested on cumulus expansion and accompanied by decreased progesterone synthesis cumulus cells during 42 hours incubation of OCC with FSH. The results showed that smoking can affect intrafollicular process, which is responsible for normal ovulation and fertilization.

The Effect of Cigarette Smoke toward the Establishment of Secondary Follicle

Univariat Anova test is used to understand the number of secondary follicle difference between groups. Univariat Anova test results can be seen in the following table :

Table 4.6: Univariat Anova test results on the number of secondary ovarian follicle of mice with cigarette smoke exposure for few weeks

\begin{tabular}{|l|l|l|l|l|l|l|}
\hline $\begin{array}{l}\text { Sources of } \\
\text { Diversity }\end{array}$ & $\begin{array}{l}\text { Sum of } \\
\text { Squares }\end{array}$ & $\begin{array}{l}\text { Degree of } \\
\text { Freedom }\end{array}$ & $\begin{array}{l}\text { Mean } \\
\text { Square }\end{array}$ & F-ratio & Significance & Description \\
\hline $\begin{array}{l}\text { Cigarette smoke } \\
\text { Observation }\end{array}$ & 7,083 & 3 & 2,361 & 6,538 & 0,001 & Significant \\
Interaction & 15,875 & 2 & 7,938 & 21,981 & 0,000 & Significant \\
Error & 9,292 & 6 & 1,549 & 4,288 & 0,002 & Significant \\
Total & 13,000 & 36 & 0,361 & & & \\
\hline
\end{tabular}

According to the table above, the number of secondary ovarian follicle of mice with exposure to cigarette smoke Univariat Anova test in a few weeks showed that cigarette smoke exposure significantly affect the number of secondary follicle with the F-ratio equal to 6.538 and a significance of 0.001 . Weeks of observation factor affects the number of secondary follicle significantly, with the F-ratio equal to 21.981 and the 
significance of 0.000 . While, the interaction between cigarette smoke exposure and weeks of observation had no significant effect on the number of secondary follicle with the F-ratio equal to 4.288 and a significance of 0.002 .

Table 4.7: HSD-Turkey test results on the number of secondary ovarian follicle of mice with cigarette smoke

\begin{tabular}{|c|c|c|}
\hline \multicolumn{3}{|c|}{ exposure } \\
\hline Cigarette Smoke Exposure & Number Of Secor & y Follicle \\
\hline Control & 4,920 & $\mathrm{c}$ \\
\hline Cigarette smoke 1 dose $/ 24$ hour & 5,080 & $\mathrm{bc}$ \\
\hline Cigarette smoke 2 doses $/ 24$ hour & 5,830 & $\mathrm{a}$ \\
\hline Cigarette smoke 3 doses $/ 24$ hour & 5,670 & $\mathrm{ab}$ \\
\hline
\end{tabular}

According to the table above, HSD-Turkey test results on the number of secondary follicle, factor of cigarette smoke exposure showed that exposure to cigarette smoke 2 dose / 24 hour had no significant difference with exposure to cigarette smoke 3 dose/ 24 hours, but significantly different from cigarette smoke exposure 1 dos/ 24 hours and control. Treatment of exposure to cigarette smoke 3 dose / 24 hours had no significant difference with the exposure to cigarette smoke with 1 dose/ 24 hour, but significantly different from the control, while the exposure to cigarette smoke 1 dose/ 24 hours had no significant difference with the control. Control treatment resulted in the lowest number of secondary follicle that is equal to 4.920 .

Table 4.8: HSD-Turkey test results on the number of secondary ovarian follicle of mice with cigarette smoke exposure for few weeks observation

\begin{tabular}{|l|rc|}
\hline Weeks of Observation & Total Number of Secondary Follicle \\
\hline 2 Weeks & 6,190 & a \\
4 Weeks & 5,000 & b \\
6 Weeks & 4,940 & b \\
\hline
\end{tabular}

According to the table above, HSD-Turkey test results on the number of secondary ovarian follicle of mice for few weeks showed that the observation of 2 weeks is significantly different with 4 weeks and 6 weeks observations, but had no significant difference from the observation of 4 weeks and 6 weeks. 6 weeks observation resulted in the lowest number of secondary follicle that is equal to 4.940 .

Table 4.9: HSD-Turkey test results on the number of secondary ovarian follicle of mice for few weeks observation

\begin{tabular}{|l|l|cl|}
\hline Cigarette Smoke Exposure & Observation & Total Number of Secondary Follicle \\
\hline Control & 2 Weeks & 6,000 & abc \\
& 4 Weeks & 4,250 & $\mathrm{~d}$ \\
& 6 Weeks & $4,500 \mathrm{~d}$ \\
\hline Cigarette smoke 1 dose/24 hour & 2 Weeks & 6,250 & $\mathrm{ab}$ \\
& 4 Weeks & 4,750 & $\mathrm{~cd}$ \\
& 6 Weeks & 4,250 & $\mathrm{~d}$ \\
\hline Cigarette smoke 2 doses/24 hour & 2 Weeks & 7,000 & $\mathrm{a}$ \\
& 4 Weeks & 5,000 & $\mathrm{bcd}$ \\
& 6 Weeks & 5,500 & $\mathrm{bcd}$ \\
\hline Cigarette smoke 3 doses/24 hour & 2 Weeks & 5,500 & $\mathrm{bcd}$ \\
& 4 Weeks & 6,000 & $\mathrm{abc}$ \\
& 6 Weeks & 5,500 & $\mathrm{bcd}$ \\
\hline
\end{tabular}

According to the table above, HSD-Turkey test results on the number of secondary follicle, combination of cigarette smoke exposure in a few weeks showed that control combination on the 4 weeks observation and combination of exposure of cigarette smoke 1 dose/24 hour on the observation of 6 weeks resulted in the lowest average number of secondary follicle that is equal to 4.250. Exposure to cigarette smoke affect the secretion of hormones that play a role in the growth of follicle. This is according to research conducted Liputo (2006) who found that exposure to cigarette smoke, affecting the endocrine system, causing disruptions that hamper the growth of follicular development. Further high levels of FSH was found in smokers in the early follicular phase and high LH of the menstrual ( Whitcomb ,2010).

Levels of exposure to cigarette smoke gives a different effect on the endocrine system, especially folliculogenesis. The more the amount of exposure to cigarette smoke, the greater the amount of disruption caused. Dechanet (2009) found in his research that the effect of smoking depends on the dose and the toxic components it contains. From the research result, the number of primary follicle, if seen from the dose or amount of exposure, indicates the exposure to 1 dose / 24 hour, the number of follicles is still high and then there is a decrease in the number of follicles on exposure 2 dose / 24 hour, and exposure to cigarette smoke 3 doses and 4 doses / 24 hour rise toward the lowest dose exposure conditions. Overview of changes in the number of secondary follicles tends to increase after a decline, may be caused by the impact of the adaptation 
mechanism. In the early exposure and with low-dose body, in this case the endocrine system and ovaries created interference yet. While at a dose of 2 doses / 24 hours, the body is unable to adapt to the toxic effects of cigarette smoke.

The Effect of Cigarette Smoke toward the Establishment of Tertiary Follicles

Univariat Anova test is used to understand the difference between groups in the number of tertiary follicles. Univariat Anova test results can be seen in the following table :

Table 4.10: Univariat Anova test results on the number of tertiary ovarian follicle of mice with cigarette smoke exposure for few weeks

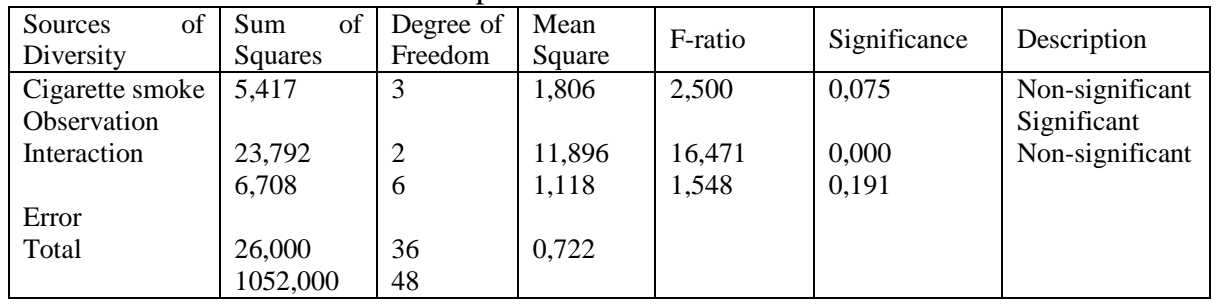

According to the table above, Univariat Anova test on the number of tertiary ovarian follicles in mice with exposure to cigarette smoke in a few weeks showed that exposure to cigarette smoke did not significantly affect the number of tertiary follicles with the F-ratio of 2500 and the significance of 0.075 . Weeks of observation factor affects the number of tertiary follicles significantly with the F-ratio equal to 16.471 and the significance of 0.000 . While the interaction between cigarette smoke exposure and weeks of observation affect no significant difference to the number of tertiary follicles with the F-ratio equal to 1.548 and a significance of 0.191 .

Table 4.11: HSD-Turkey test results on the number of tertiary ovarian follicle of mice for few weeks observation

\begin{tabular}{|l|rc|}
\hline Weeks of Observation & Number of Tertiary follicles \\
\hline 2 weeks & 5,190 & $\mathrm{a}$ \\
4 weeks & 4,880 & $\mathrm{a}$ \\
6 weeks & 3,560 & $\mathrm{~b}$ \\
\hline
\end{tabular}

According to the table above, HSD-Turkey test results on the number of tertiary follicles in a few weeks observation showed that a two-week and four-week observations had no significant different, but significantly different from a six-week observation. The six-week observation resulted in the lowest number of tertiary follicles that is equal to 3.560. Less significant difference in the number of tertiary follicles in this research was likely due to the exposure to cigarette smoke poses no change or interruption on the tertiary follicle formation. The new changes can be identified after several years of exposure to cigarette smoke, based on the research.

The process of oocyte maturation influenced exposure dose, this case is in accordance with the results of research of Zenzes (1997) who found a positive correlation between the number of cigarettes smoked and the number of follicles. The research also found that there is a positive correlation between cotinine levels and the rate of oocyte maturation. The delay of development and oocytes maturation also occur on Cd accumulation in the ovaries (Lienesch et al. (2000).

\section{The Effect of Cigarette Smoke toward the Establishment of Follicle De Graaf}

Univariat Anova test is used to understand the difference between groups in the number of follicle de Graaf. Univariat Anova test results can be seen in the following table :

Table 4.12: Univariat Anova test results on the number of ovarian follicle de Graaf in mice with cigarette smoke exposure for few weeks

\begin{tabular}{|l|l|l|l|l|l|l|}
\hline $\begin{array}{l}\text { Sources of } \\
\text { Diversity }\end{array}$ & $\begin{array}{l}\text { Sum of } \\
\text { Squares }\end{array}$ & $\begin{array}{l}\text { Degree of } \\
\text { Freedom }\end{array}$ & $\begin{array}{l}\text { Mean } \\
\text { Square }\end{array}$ & F-ratio & Significance & Description \\
\hline $\begin{array}{l}\text { Cigarette smoke } \\
\begin{array}{l}\text { Observation } \\
\text { Interaction }\end{array}\end{array}$ & 1,563 & 3 & 0,521 & 0,478 & 0,700 & $\begin{array}{l}\text { Non-significant } \\
\text { Significant } \\
\text { Non- significant }\end{array}$ \\
Error & 28,042 & 2 & 14,021 & 12,860 & 0,000 & \\
Total & 6,125 & 6 & 1,021 & 0,963 & 0,481 & \\
& 39,250 & 36 & 1,090 & & & \\
\hline
\end{tabular}


According to the table above, the Univariat Anova test on the number of follicle de Graaf in mice with exposure to cigarette smoke in a few weeks showed that exposure to cigarette smoke did not significantly affect the number of follicle de Graaf with the F-ratio equal to 0,478 and significance of 0,700. Weeks of observation factor affects the number of follicle de Graaf significantly with the F-ratio equal to 12.860 and the significance of 0.000. While the interaction between cigarette smoke exposure and weeks of observation affects no significant difference to the follicle de Graaf with the F-ratio equal to 0.963 and a significance of 0.481 .

Table 4.13; HSD-Turkey test results on the number of follicle de Graaf in mice on several weeks of observation

\begin{tabular}{|c|c|}
\hline Weeks of Observation & Total Number of Folicle de Graaf \\
\hline 2 weeks & 4,060 \\
\hline 4 weeks & 2,750 \\
\hline 6 weeks & 2,250 \\
\hline
\end{tabular}

According to the table above , HSD-Turkey test results on the number of follicle de Graaf on several weeks of observation showed that a two-week observation was significantly different from a four-week and sixweek observations, while a four-week and six-week observation was not significantly different. The six-week observation produced the lowest amount of follicle de Graaf produced the lowest amount that is equal to 2.250 . The biggest last follicle in the ovary is the follicle de Graaf (Sastrawinata, 1994). Follicle de Graaf does not depend on FSH secretion from the pituitary and follicle de Graaf produce their own estrogen from theca cells, and estrogen levels continue to rise, as a result of increased levels of estrogen, retention of fluid and sodium in the body's tissues occurs. This condition also causes suppression of FSH hormone while LH affect the final stages of follicular maturation (Verralls , 2003).

\section{Conclusion}

\section{Conclusion And Recommendation}

1. Exposure to cigarette smoke within 6 weeks has significant influence on the formation of primary follicles in mice.

2. The overall exposure to cigarette smoke i.e. 2 weeks, 4 weeks and 6 weeks has significant influence on the formation of secondary follicles in mice.

3. The overall exposure to cigarette smoke i.e. 2 weeks, 4 weeks and 6 weeks has no significant influence on the formation of tertiary follicles in mice.

4. Exposure to cigarette smoke in a period of 6 weeks has no significant influence on the formation of follicle de Graaf in mice.

\section{Recommendation}

1. If you conduct some research on cigarette smoke exposure in mice follicles, do it in a considerably long time.

2. Further study is required on cigarette smoke exposure in mice follicles by seeing the maturity and structure of the follicle.

\section{References}

[1]. Campbell DT dan Stanley JC, 1963. Experimental Design for Research Rand.Chicago : Mc Nally College Publishing Company.

[2]. Cochran W.G, 1991. Teknik Penarikan Sampel, Edisi Ketiga. Terjemahan Rusdiansyah. Jakarta : Penerbit Universitas Indonesia.

[3]. Dorland, 2005, Kamus Kedokteran, Edisi ke dua puluh delapan, EGC, Jakarta. Hal 726 - 727.

[4]. Ganong WF, 1999. Review of Medical Physiology, $19^{\text {th }}$ ed. Stand Ford Connecticut:

[5]. Ganong, WF. 2003, Buku Ajar Fisiologi Kedokteran, Edisi 20, EGC, Jakarta Hal.417-431.

[6]. Greenspand FS and Forshan PH, 1997. Basic and Clinical Endocrinology, $5^{\text {th }}$ ed. Stand Ford Connecticut : Appleton and Large, pp 545-567.

[7]. Guyton dan Hall, 1997, Buku Ajar Fisiologi Kedokteran Cetakan 1, EGC, Jakarta, Hal; 1283-1302.

[8]. Hardjo Pronjoto, 1995. Ilmu Kemajiran Ternak. Surabaya: Airlangga University Press.

[9]. Heyne K, 1987. Tumbuhan Berguna Indonesia, Jilid 11. Jakarta : Badan Penelitian dan Pengembangan Kehutanan RI, hlm 840-842.

[10]. Hunter RHF, 1993. Fisiologi dan Teknologi Reproduksi Hewan Betina Domestik. Bandung: Penerbit ITB.

[11]. Ismudiono, 1999.Embriologi Reproduksi pada Ternak. Surabaya: FKH Universitas Airlangga.

[12]. Johnson M, 1995. Essential Reproduction, $4^{\text {th }}$ Edition. London: Department of Embriology and Department of Experimental of Psychology University of Cambridge.

[13]. Limbong T, 2004, Pengawas Ekstrak Etanol Kulit Batang Pakettu (Ficus superbamiq) Terhadap Foklulogenesis Ovarium Mencit (Mus musculus) Tesis, Universitas Airlangga Surabaya.

[14]. Marge K, Judith T and Gay, 1997. Kesehatan Wanita. Yogyakarta: Universitas Gajah Mada.

[15]. Mursito B, 2001. Ramuan Tradisional untuk Kesehatan Ibu Hamil.Jakarta Penerbit Swadaya.

[16]. Partodihardjo S, 1992. Ilmu Reproduksi Hewan. Jakarta: Penerbit Mutiara, h1m 43-52; 105-108; $173-181$.

[17]. Prawirohardjo, 1991.llmu Kebidanan, Cetakan Kelima. Yayasan Bina Pustaka Sarwono, Hal; 64-85.

[18]. Purnomo SM, 2002. Pengembangan Obat Tradisional dalam Dunia Pengobatan. Surabaya: Kanwil Depkes Propinsi Jawa Timur.

[19]. Sarwono, 1994. Ilmu Kandungan. Jakarta: Yayasan Bina Pustaka Sarwono Prawirohardjo, hlm 544-545: 634-643.

[20]. Speroff L, MD and Phillip D, 1996. A Clinical Guide for Contraception, $22^{\text {nd }}$ edition. San Francisco: University of California, pp 35-37. 
[21]. Speroff L, Robert H, and Nathan GK, 2005.Clinical Embriology Gynecology Endocrinology and Infertility, $5^{\text {th }}$ edition. Baltimore London: William and Williams Co, pp 76-85.

[22]. Tambajong J, 1990, Buku Ajar Histology, EGC, Jakarta, Hal; 480-509.

[23]. Verralls S, 2003, Anatomi dan Fisiologi Terapan Dalam Kebidanan, Edisi 3. Jakarta, EGC, Hal; 161-173. 